\title{
Varactor-tuned Substrate Integrated Evanescent Filter
}

\author{
Zhurbenko, Vitaliy; Acar, Öncel; Dong, Yunfeng
}

Link to article, DOI:

10.1109/URSI-AT-RASC.2015.7302854

Publication date:

2015

Document Version

Publisher's PDF, also known as Version of record

Link back to DTU Orbit

Citation (APA):

Zhurbenko, V., Acar, Ö., \& Dong, Y. (2015). Varactor-tuned Substrate Integrated Evanescent Filter. Abstract from 1st URSI Atlantic Radio Science Conference, Gran Canaria, Spain. https://doi.org/10.1109/URSI-ATRASC.2015.7302854

\section{General rights}

Copyright and moral rights for the publications made accessible in the public portal are retained by the authors and/or other copyright owners and it is a condition of accessing publications that users recognise and abide by the legal requirements associated with these rights.

- Users may download and print one copy of any publication from the public portal for the purpose of private study or research.

- You may not further distribute the material or use it for any profit-making activity or commercial gain

- You may freely distribute the URL identifying the publication in the public portal

If you believe that this document breaches copyright please contact us providing details, and we will remove access to the work immediately and investigate your claim. 


\title{
Varactor-tuned Substrate Integrated Evanescent Filter
}

\author{
Vitaliy Zhurbenko $^{(1)}$, Öncel Acar ${ }^{(1)(2)}$ Yunfeng Dong $^{(1)}$ \\ (1) Technical University of Denmark, 2800 Kgs. Lyngby, Denmark \\ (2) MTI Radiocomp, Krakasvej 17, 3400 Hillerød, Denmark
}

Evanescent mode waveguides allow for more compact microwave component design in comparison to the traditional fundamental mode waveguide technology. Evanescent waveguides can be integrated into a dielectric substrate in order to further reduce the mass and volume. Unfortunately, traditional realization methods used in the standard evanescent waveguides are often not directly applicable to substrate integrated waveguide (SIW) technology due to dielectric filling and small height of the waveguide. In this work, one of the realization methods of evanescent waveguides using lumped elements is considered. In contrast to other methods described in the literature, it avoids etching split ring resonators in the metal layer of the SIW. The filters presented here use varactors as tuning elements. The varactors (as well as DC decoupling circuits) are mounted on the surface of PCB bringing the lower metal layer of the waveguide to the top layer with metalized via holes.

The present filters are analyzed using models based on impedance matrix representation. The developed models allow computationally efficient and relatively accurate prediction of the filter behavior in a wide frequency range (at least up to frequencies below the cut-off of the second propagating mode).

This work investigates the applicability of the evanescent SIW approach to tunable filter realization. The advantages and disadvantages of the approach are analyzed. As an example, a second order microwave filter is designed, fabricated and tested in order to validate the developed filter models as well as the implemented realization method. The filter structure as well as its tuning are shown in Figure 1.

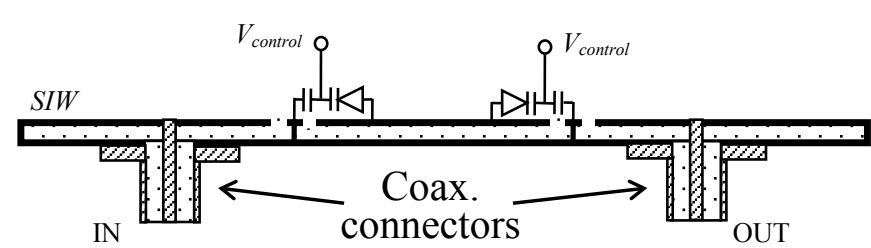

(a)

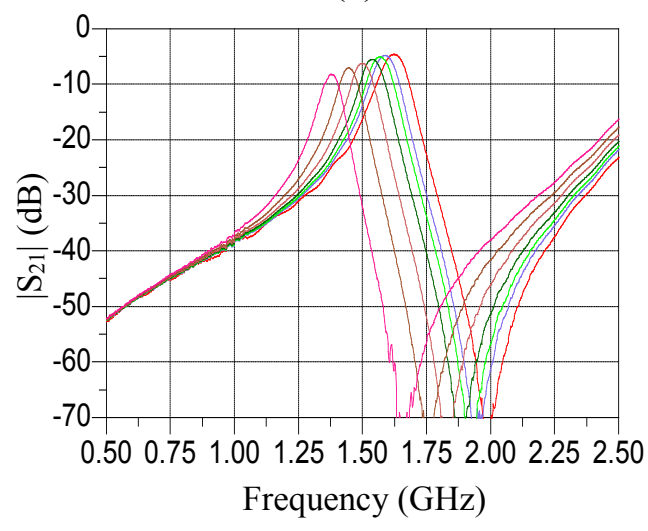

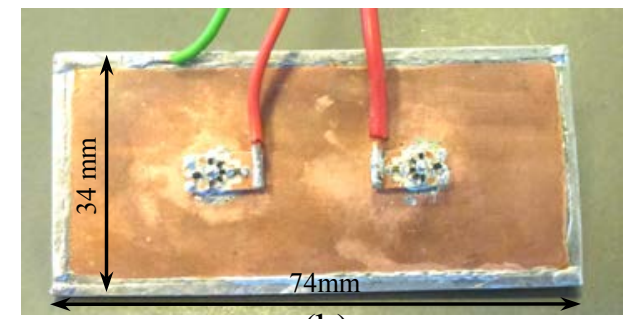

(b)

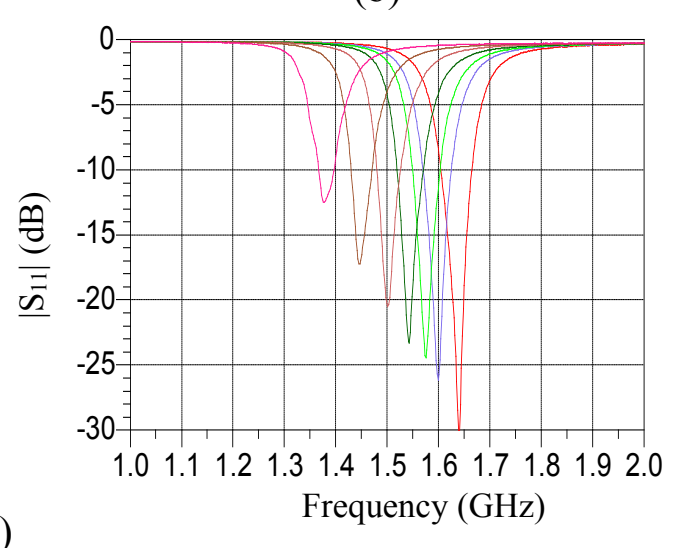

(c)

Figure 1. Example of a substrate integrated waveguide (SIW) tunable evanescent filter (a) schematic representation, (b) realization, (c) scattering parameters. 